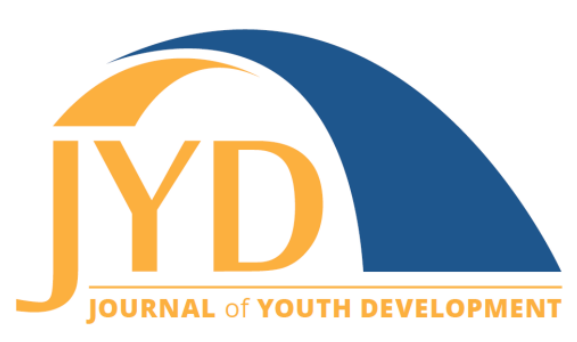

http://jyd.pitt.edu/ | Vol. 16 Issue 4 DOI 10.5195/jyd.2021.933 | ISSN 2325-4017 (online)

\title{
Validation of a Protective and Promotive Factors Measure: The Youth Thrive Survey
}

\author{
Charlyn Harper Browne \\ Center for the Study of Social Policy \\ charlyn.harperbrowne@cssp.org \\ Lisa Mishraky-Javier \\ Center for the Study of Social Policy \\ lisa.mishraky@cssp.org
}

\begin{abstract}
This article describes the background, development, and validation of the strengths-based, youth-driven Youth Thrive Survey which measures the 5 protective and promotive factors delineated in the Youth Thrive Framework; specifically: youth resilience, social connections, knowledge of adolescent development, concrete support in times of need, and cognitive and social-emotional competence. Draft instruments were created that included new items and adapted items from existing validated instruments. Revisions were based on feedback from young people who participated in focus groups, cognitive interviews, and field testing. Cronbach's alpha was calculated to measure internal consistency and reliability of the full instrument and the 5 protective and promotive factor subscales. Principal component analyses revealed items that did not fit well within the instrument structure and subsequently were eliminated. Analyses of the final version of the instrument showed that the Youth Thrive Survey has high levels of internal consistency and reliability. All alphas for the subscales were greater than 0.80 and the alpha for the full instrument was 0.963. This web-based, self-report survey is appropriate for use by organizations serving young people ages 12 to 26, both those who are involved with child welfare and juvenile justice systems and those who have no history of such involvement. It can be used for assessment and case planning with youth, program evaluation, and continuous quality improvement. The Youth Thrive Survey, available in English and Spanish, shows great promise and utility for organizations that employ positive youth development approaches.
\end{abstract}

Key words: youth assessment tool, protective and promotive factors, adolescent development, youth well-being, thriving

Adolescence is a period of rapid growth and significant physical, social, emotional, and cognitive change; it is also a period marked by risk for many behavioral, social, and health-related

(cc) EY New articles in this journal are licensed under a Creative Commons Attribution 4.0 License. This journal is published by the University Library System, University of Pittsburgh and is cosponsored by the University of Pittsburgh Press. The Journal of Youth Development is the official peer-reviewed publication of the National Association of Extension 4-H Youth Development Professionals and the National AfterSchool Association. 
challenges. Research focused on this timeframe has yielded important understandings about risk factors and vulnerabilities during adolescence (Richter, 2006). Over the past two decades, advances in neuroscience and developmental psychology have yielded much new knowledge about adolescent development and have led to an expanded timeframe of adolescence that considers neurological changes that occur well into young adulthood (Bronfenbrenner Center for Translational Research, 2013; Casey et al., 2008; Jaworska \& MacQueen, 2015; National Institute of Mental Health, 2011). Substantial progress also has been made in the theoretical understanding of adolescent development as a period of great opportunity to promote positive trajectories for young people by focusing on their unique strengths and protective factors in order to help them successfully navigate challenges and realize their potential (Dahl, 2004; United Nations Children's Fund, 2011).

Increasingly, prevention scientists, researchers, practitioners, and policymakers have viewed positive youth development (PYD) approaches as key in developing youths' strengths and competencies, reducing the likelihood of negative risk behaviors, and promoting a successful transition to adulthood (Catalano et al., 2002; Catalano 2010; Ciocanel et al., 2017; Lerner, 2009). The federal Interagency Working Group on Youth Programs defined PYD:

An intentional prosocial approach that engages youth within their communities, schools, organizations, peer groups, and families in a manner that is productive and constructive; recognizes, utilizes, and enhances youths'strengths; and promotes positive outcomes for young people by providing opportunities, fostering positive relationships, and furnishing the support needed to build on their leadership strengths. (Dymnicki et al., 2016, p. 8)

Studies of PYD programs have provided growing evidence of effectiveness with respect to improving the social, emotional, and academic skills of youth (Durlak et al., 2011); engaging in prosocial behaviors such as civic involvement and providing support to others (Gavin et al., 2010; Lerner \& Lerner, 2013); and preventing negative risk behaviors such as youth violence and drug use (Guerra \& Bradshaw, 2008). Although the evidence base about the effectiveness of PYD programs is growing, a Federal Research Agenda for Positive Youth Development delineated several gaps in the field, two of which are the need for (a) measurement of PYD at the individual, relationship, community, societal, and system levels and (b) valid and reliable measures of PYD (Dymnicki, et al., 2016). The Youth Thrive Survey is a viable response to these two needs. 
This article describes the background, development, and validation of the Youth Thrive Survey. The results of the initial validation study provide evidence that the Youth Thrive Survey shows potential to be a valid and reliable web-based, self-report instrument designed to measure the presence of the five protective and promotive factors delineated in the Youth Thrive Framework, a framework that reflects the core principles of the PYD approach.

\section{Background: The Youth Thrive Protective and Promotive Factors Framework}

Introduced in 2011, the Youth Thrive (YT) Framework is an approach for supporting healthy development for all youth and young adults (ages 9 to 26), including those involved in intervening public systems (e.g., child welfare, juvenile justice, behavioral health) and those who have experienced trauma and other significant challenges. The YT Framework is grounded in the idea that all young people have strengths, resources, and the capacity for positive growth and development (Fergus \& Zimmerman, 2005). At the foundation of the YT Framework are five interrelated variables that are simultaneously protective factors-which reduce the impact of negative life experiences, and promotive factors-which advance healthy development and well-being. The YT protective and promotive factors are youth resilience, social connections, knowledge of adolescent development, concrete support in times of need, and cognitive and social-emotional competence. Taken together, these factors are individual and relational processes, characteristics, and abilities, as well as community and social conditions, which help to accomplish the following:

- Proactively address challenges and adversity.

- Build individual strengths.

- Promote healthy development and well-being.

- Encourage positive risk-taking (e.g., civic engagement, school sports) and discourage negative risk-taking (e.g., binge drinking, texting while driving).

- Foster collaboration across service sectors.

- Establish environments and experiences that help youth to reach their potential as productive and engaged adults.

\section{Youth Resilience}

Resilience is the process of positive adaptation (e.g., coping, problem solving, becoming more resourceful, functioning well) despite experiencing significant challenges, adversity, or trauma (Luthar, 2003; Luthar \& Cicchetti, 2000; National Scientific Council on the Developing Child, 2015; Werner, 2000). Resilience is not a personality trait that one has or does not have; rather, it involves positive behaviors and attitudes that anyone can develop (American Psychological 
Association, 2019; Easterbrooks et al., 2013; Luthar \& Cicchetti, 2000; Masten, 2001). Demonstrating resilience enables youth and young adults to see evidence of their ability to face challenges competently and take control over their lives in healthy ways, be accountable for their actions and the consequences of their actions, internalize the belief that their lives are important and meaningful, and envision and conscientiously work with purpose and optimism toward future possibilities for themselves (Murphey et al., 2013).

\section{Social Connections}

Social connections are young peoples' (a) healthy and sustained relationships with caring, supportive family members, other adults, peers, and close friends; (b) physically and emotionally safe, stable, and equitable environments-such as schools, neighborhoods, and community organizations-that provide opportunities for constructive engagement as learners, leaders, team members, and workers (Novick et al., 2018); and/or (c) belief in a higher power that helps youth to find meaning and a positive purpose in their lives. Research has confirmed that youth need to feel connected to someone or some entity in order to thrive, and that a sense of connectedness is protective against many health risk behaviors (Novick et al., 2018; Resnick, 2005). Healthy social connections help to promote a sense of trust, belonging, and a belief that one matters.

\section{Knowledge of Adolescent Development}

If parents and adults who work with and on behalf of youth have accurate knowledge about the unique aspects of adolescent development and stay abreast of the realities and complexities of adolescents' lives today, they can provide more developmentally informed support, guidance, and encouragement for the young people in their personal and professional contexts (U.S. Department of Health and Human Services, Office of Adolescent Health, 2018). Young people themselves can benefit from increasing their understanding about adolescent development, in general, and their own development, in particular, because this helps to normalize their individual experiences as developmentally typical. Key areas in which increased knowledge would be helpful include (a) adolescent brain development; (b) racial, ethnic, and gender identity development; (c) challenges and concerns faced by young people today; and (d) implementing developmentally and contextually appropriate best practices with youth and young adults. 


\section{Concrete Support in Times of Need}

Concrete support in times of need refers to help-seeking behavior, access to developmentally focused services, and respectful service delivery. Help-seeking is an important life skill that can promote self-sufficiency in navigating the complex web of medical, mental health, and social service systems. Help-seeking is also a protective factor for adolescent health and overall satisfaction with life (Barker, 2007; Unrau et al., 2006). Young people need access to accurate information and high-quality resources and services that are tailored to their unique developmental stage (Novick et al., 2018). Concrete support should be provided in a manner that preserves youths' dignity, provides opportunities to learn to advocate for oneself, and helps to minimize the negative impact of adversity and traumatic experiences.

\section{Cognitive and Social-Emotional Competence}

Cognitive and social-emotional competence refers to interrelated components that studies show are linked to structural and functional changes in brain development that occur during adolescence and young adulthood (see, e.g., Choudhury et al., 2006; Crone, 2009; Keating, 2004; Steinberg, 2005). Cognitive and social-emotional competence includes the knowledge, attitudes, and abilities that lay the foundation for more mature learning skills, problem solving, and decision making; forming an independent identity; effectively interacting, communicating, and collaborating with others; and having a productive, responsible, and satisfying adulthood. Strong cognitive and social-emotional abilities-such as consequential thinking, self-regulation, and positive self-worth-will help youth and young adults to be better equipped to handle stress and persevere through significant challenges and adversity in their lives.

\section{Building the VT Protective and Promotive Factors}

A basic premise of the YT framework is that youth-both in general and those at high risk of negative outcomes-have a greater likelihood of achieving healthy outcomes if they are engaged in environments and experiences that support the building of the YT protective and promotive factors. Researchers (see, e.g., American Psychological Association, 2019; Easterbrooks et al., 2013; National Scientific Council on the Developing Child, 2015) report that resilience, social connections, knowledge development, concrete support, and cognitive and social-emotional competence are facilitated by environments and experiences that meet the following goals:

1. Identify and build on youths' strengths.

2. Provide positive experiences, guidance, and a stable relationship with at least one caring, competent adult. 
3. Foster positive peer relationships.

4. Encourage an optimistic belief that one's circumstances can be improved through a commitment to change and consistent effort.

5. Teach healthy ways to manage currently stressful events and identify new patterns of responding to future stressful situations.

6. Promote high, achievable expectations and goals.

7. Enhance self-knowledge, self-worth, self-confidence, and self-compassion.

8. Provide opportunities for constructive engagement in their family, community, school, and other social institutions.

9. Encourage youth and young adult voice, choice, and personal responsibility.

10. Forge collaborations across community sectors.

\section{Development of the Youth Thrive Survey}

Although considerable advances have been made in promoting positive developmental experiences and outcomes for youth (Peterson \& Seligman, 2004), measures of adolescent wellbeing in the United States continue to typically focus on negative indicators of youth outcomes, orienting policy and practice towards the prevention of problems over the promotion of protective and promotive factors. The Youth Thrive Survey offers a valuable addition to existing measures of adolescent well-being, providing a common set of positive and multidimensional constructs. A review of existing youth measures revealed that there were several instruments that assessed some of the indicators of the YT protective and promotive factors independently, but there was not a single instrument that was designed to measure the presence, strength, and growth of all five factors. In addition, many youth measures focus on diagnosing disorders (Cox, 2006) or the identification of risk and protective factors associated with problem behaviors (Arthur et al., 2002). An emphasis on problems and deficits tends to obscure the recognition of youth's strengths and capabilities that could serve as resources for addressing challenges and promoting well-being.

Epstein (2004) emphasized the importance of strengths-based youth assessment that is "the measurement of those emotional and behavioral skills, competencies, and characteristics that create a sense of personal accomplishment; contribute to satisfying relationships; . . . enhance one's ability to deal with adversity and stress; and promote one's personal, social, and academic development" (p. 4). The strengths-based youth assessment tools that were reviewed primarily focused on positive personality traits. In contrast, the YT protective and promotive factors are 
The Youth Thrive Survey

individual and relational processes, characteristics, and abilities, as well as community and social conditions.

The following is a description of the process used to develop and validate the Youth Thrive Survey. Central to the validation process was including young people in various stages. The psychometric properties of the instrument that were derived from a multistage validation process are provided.

\section{Method}

\section{Instrument Development}

The first stage in the development of the Youth Thrive Survey involved (a) identifying characteristics of the five protective and promotive factors, (b) reviewing existing validated youth measures that assess constructs related to the YT protective and promotive Factors, and (c) creating new survey items based on literature and expert review. Core characteristics of each of the protective and promotive factors are provided in Table 1. It is important to note that the core characteristics of one factor may relate to another factor as well because the five protective and promotive factors are interrelated.

Table 1. Core Characteristics and Definitions of the YT Protective and Promotive Factors

\begin{tabular}{|l|c|}
\hline $\begin{array}{l}\text { YT protective and promotive } \\
\text { factors and definitions }\end{array}$ & Core characteristics and competencies \\
\hline $\begin{array}{l}\text { Youth resilience: Positive } \\
\text { adaptation and personal growth } \\
\text { despite experiencing adversity or }\end{array}$ & $\begin{array}{l}\text { - Positive coping skills and functioning well despite adversity or } \\
\text { trauma }\end{array}$ \\
& trauma \\
& agency regarding one's ability to manage challenges and \\
& - Sense of personal growth after positively/successfully facing \\
& challenges \\
& - Optimism, hope, faith \\
& - Persistence; seeing alternate solutions to problems \\
\hline
\end{tabular}


The Youth Thrive Survey

Table 1. (continued)

\begin{tabular}{|c|c|}
\hline $\begin{array}{l}\text { YT protective and promotive } \\
\text { factors and definitions }\end{array}$ & Core characteristics and competencies \\
\hline $\begin{array}{l}\text { Social connections: Healthy, } \\
\text { sustained relationships with } \\
\text { people, institutions, communities, } \\
\text { and/or a higher power }\end{array}$ & $\begin{array}{l}\text { - Healthy relationships with significant adults and peers; having } \\
\text { - } \text { - Constructive engagement in social institutions, organizations, } \\
\text { or activities } \\
\text { - Sense of spiritual connectedness } \\
\text { - Contributing to a social good } \\
\text { - Sense of belonging and mattering; feeling valued }\end{array}$ \\
\hline $\begin{array}{l}\text { Knowledge of adolescent } \\
\text { development: Understanding the } \\
\text { unique aspects of adolescent } \\
\text { development; promoting healthy } \\
\text { development and well-being }\end{array}$ & $\begin{array}{l}\text { - Self-awareness; conscientiously reflecting on one's challenges } \\
\text { and concerns and taking steps to address them } \\
\text { - Healthy racial, ethnic, and gender identities } \\
\text { - Accurate knowledge of the common/expected developmental } \\
\text { changes of adolescence and young adulthood } \\
\text { - Accurate knowledge of one's own developmental changes }\end{array}$ \\
\hline $\begin{array}{l}\text { Concrete support in times of } \\
\text { need: Proactive help-seeking } \\
\text { behavior and high-quality service } \\
\text { delivery; knowledge of } \\
\text { developmentally appropriate and } \\
\text { quality resources, services, and } \\
\text { supports }\end{array}$ & $\begin{array}{l}\text { - Engaging in proactive help-seeking } \\
\text { - Self-advocacy, self-determination } \\
\text { - Knowledge of and access to relevant resources, services, and } \\
\text { supports } \\
\text { - Being treated respectfully and fairly when seeking and } \\
\text { receiving help }\end{array}$ \\
\hline $\begin{array}{l}\text { Cognitive and social-emotional } \\
\text { competence: Knowledge, } \\
\text { attitudes, and skills that are } \\
\text { essential for forming an } \\
\text { independent identity and having a } \\
\text { productive, responsible, and } \\
\text { satisfying adulthood }\end{array}$ & $\begin{array}{l}\text { - Experiencing positive emotions; being aware of triggers that } \\
\text { evoke negative emotions; proactively managing negative } \\
\text { emotions } \\
\text { - Exercising control over one's thinking, behavior, and emotions } \\
\text { - Abstract thinking; planning and thinking ahead } \\
\text { - Character strengths (e.g., empathy, sense of right and wrong, } \\
\text { conscientiously reflecting and acting on what one desires to } \\
\text { become and not become) }\end{array}$ \\
\hline
\end{tabular}

New items were created and a review of items and survey response scales in existing validated instruments was conducted in order to compile a comprehensive item bank and list of response formats. A review of the initial item bank and recommended response scale was conducted, 
with input from three young people, to determine relevance of the items to the protective and promotive factors and to ensure that the items were worded clearly and appropriately for a fifth-grade reading level.

As a result of this initial review, the item bank was reduced to 162 -items which were organized into five subscales, one for each of the protective and promotive factors. The draft instrument also included 11 background questions and used a Likert-type response scale (Not at all like me, A little like me, Sort of like me, A lot like me, or Very much like me). The draft instrument and all testing protocols were submitted to an Institutional Review Board (IRB) to ensure compliance with ethical standards for research with human participants. Subsequent revisions to the instrument were also submitted to the IRB for review and approval.

\section{Validation Process}

Following IRB approval, a three-stage validation process was employed that included conducting focus groups, cognitive testing, and two rounds of field testing.

\section{Stage 1: Focus Groups.}

From July to September 2016, four 1-hour focus groups were conducted with a diverse set of young people including LGBTQ+ youth and young adults (eight participants, ages 18 to 22); two groups of African American youth (11 participants involved in a church group, ages 11 to 18 and 14 participants involved in a community organization, ages 11 to 17); and youth and young adults who lived in group homes due to child welfare involvement, including young mothers (13 participants, ages 16 to 22). The purpose of the focus groups was to gather participants' feedback on the background questions, response scale, and survey items; uncover potential problems that may impact the instrument's validity; identify possible solutions; and revise the instrument accordingly. Participants were asked whether each item made sense, whether it would be easy to answer using the response scale, and whether it was biased in any way. Participants also suggested changes to various items. The young people received a $\$ 50$ gift card for their participation.

Feedback from focus group participants resulted in the elimination and re-wording of some items to make them simpler, clearer, or less biased. In addition, a text analysis of the items was conducted to identify overlap in content within and across the subscales. As a result of the focus group feedback and text analysis, 67 items were eliminated from the draft instrument; 
The Youth Thrive Survey

the next iteration of the instrument was comprised of 95 items. This second draft was programmed into an online survey tool for subsequent stages in the validation process.

\section{Stage 2: Cognitive Interviews.}

Cognitive interviews were conducted in December 2016 with 11 youth and young adults, ages 15 to 26 , who were affiliated with a community-based organization, an LGBTQ+ Center, and a social service organization. After completing the web-based or paper version of the 95 -item instrument in its entirety, participants discussed how they arrived at their answers to the items, what specific words meant to them, and whether any items were unclear or difficult to answer. Interviewees received a $\$ 50$ gift card for their participation. Results of the cognitive interviews were used to further reword some items, eliminate three items, and finalize a draft instrument for field testing. This draft version included 92 items.

\section{Stage 3: Field Testing.}

A purposive sampling plan was developed prior to field testing. Purposive sampling is used when researchers want to access a subset of individuals based on agreed-upon characteristics and the objective of a study (Etikan, 2016). The plan employed for field testing targeted a diverse range of respondent characteristics, specifically: age range, race/ethnicity, gender identity, and being currently homeless or involved in the juvenile justice or foster care systems. Target numbers were determined for each respondent subgroup based on a target $N$ of 500 for each field-testing round. Round 1 took place from April to June 2017 and Round 2 from July to October 2017. No incentives were offered to young people for their participation in either round of field testing.

Round 1. Youth and young adults from 125 organizations were invited to take the 92 -item instrument online. The entire survey-that is, all five subscales-was completed by 316 participants. The median time to complete the survey was 10 minutes, with 73 percent of respondents completing it in 15 minutes or less.

Data analyses and findings, Round 1. Cronbach's alpha is an established measure of internal consistency and estimate of reliability. Cronbach's alpha was calculated for the full instrument, as well as for each of the instrument's five subscales: youth resilience (YR), social connections (SC), knowledge of adolescent development (KAD), concrete support in times of need (CS), and cognitive and social-emotional competence (CSE). As seen in Table 2, both the full instrument and each subscale appear to be highly reliable, with all internal consistency coefficients (alpha) greater than 0.85 . The alpha for the full instrument was 0.97 . 
The Youth Thrive Survey

Table 2. Cronbach's Alpha, 92-Item Instrument

\begin{tabular}{|c|c||c|c|c|c|c|}
\hline & $\begin{array}{c}\text { Full } \\
\text { instrument }\end{array}$ & $\begin{array}{c}\text { Subscale 1 } \\
(\mathbf{Y R})\end{array}$ & $\begin{array}{c}\text { Subscale 2 } \\
\text { (SC) }\end{array}$ & $\begin{array}{c}\text { Subscale 3 } \\
\text { (KAD) }\end{array}$ & $\begin{array}{c}\text { Subscale 4 } \\
\text { (CS) }\end{array}$ & $\begin{array}{c}\text { Subscale 5 } \\
\text { (CSE) }\end{array}$ \\
\hline$N$ & 316 & 381 & 377 & 378 & 402 & 386 \\
\hline Items & 92 & 15 & 23 & 23 & 11 & 20 \\
\hline Alpha & 0.970 & 0.894 & 0.893 & 0.943 & 0.921 & 0.878 \\
\hline
\end{tabular}

Note. $\mathrm{YR}=$ youth resilience, $\mathrm{SC}=$ social connections, $\mathrm{KAD}=$ knowledge of adolescent development, $\mathrm{CS}=$ concrete support in times of need, and CSE = cognitive and social-emotional competence.

Next, a set of data reduction analyses-principal component analyses (PCAs) - were conducted to further understand the relationship between the survey items and their relationship to the subscales. Specifically, PCAs are conducted to reduce a large set of variables (in this case, 92 survey items) to a smaller set that still accurately reflects the larger set (Dunteman, 1989). The initial PCA revealed several items that were equally loaded across subscales or loaded weakly within a subscale; thus, they did not fit well within the instrument structure and were eliminated. Subsequent PCAs were conducted to account for as much of the remaining variability as possible.

Through this iterative process, the instrument was reduced to 66 items based on the strength of the relationship and relevance of an item to the respective protective and promotive factor subscale. Cronbach's alpha was calculated for the 66-item instrument, as well as for each of the instrument's five subscales. Table 3 shows that both the full instrument and each subscale appear to be highly reliable, with all internal consistency coefficients greater than 0.80 . The alpha for the full instrument was 0.957 .

Table 3. Cronbach's Alpha, 66-Item Instrument-Round 1

\begin{tabular}{|c|c||c|c|c|c|c|}
\hline & $\begin{array}{c}\text { Full } \\
\text { instrument }\end{array}$ & $\begin{array}{c}\text { Subscale 1 } \\
\text { (YR) }\end{array}$ & $\begin{array}{c}\text { Subscale 2 } \\
\text { (SC) }\end{array}$ & $\begin{array}{c}\text { Subscale 3 } \\
\text { (KAD) }\end{array}$ & $\begin{array}{c}\text { Subscale 4 } \\
\text { (CS) }\end{array}$ & $\begin{array}{c}\text { Subscale 5 } \\
\text { (CSE) }\end{array}$ \\
\hline$N$ & 331 & 385 & 382 & 385 & 402 & 391 \\
\hline Items & 66 & 10 & 17 & 13 & 10 & 16 \\
\hline Alpha & 0.957 & 0.843 & 0.871 & 0.918 & 0.914 & 0.844 \\
\hline
\end{tabular}

Note. $\mathrm{YR}=$ youth resilience, $\mathrm{SC}=$ social connections, $\mathrm{KAD}=$ knowledge of adolescent development, $\mathrm{CS}=$ concrete support in times of need, and CSE = cognitive and social-emotional competence. 
The purpose of these analyses was to streamline the 92 -item instrument as much as possible and ensure that the reduced instrument demonstrated sufficient reliability to engage in a second round of field testing. Although the 92-item instrument demonstrated high internal consistency and reliability, eliminating 26 items produced a shorter, more focused instrument with reliability estimates similar in magnitude to the 92 -item instrument. The 66 -item instrument was the final version examined in the validation study.

Round 2. The same organizations from the first round of field testing were contacted, as well as some additional organizations, to help recruit youth and young adults for the second round. The entire online survey was completed by 204 participants. The median time to complete the survey was seven minutes, with 83 percent of respondents completing it in 15 minutes or less.

Data analyses and findings, Round 2. Reliability and validity analyses were conducted on the 66-item instrument. Cronbach's alpha was calculated for the full instrument and the five subscales. Table 4 shows that both the full instrument and each subscale appear to be highly reliable, with all internal consistency coefficients greater than 0.80 . The alpha for the full instrument was 0.963 .

Table 4. Cronbach's Alpha, 66-Item Instrument-Round 2

\begin{tabular}{|c|c||c|c|c|c|c|}
\hline & $\begin{array}{c}\text { Full } \\
\text { instrument }\end{array}$ & $\begin{array}{c}\text { Subscale 1 } \\
(\mathbf{Y R})\end{array}$ & $\begin{array}{c}\text { Subscale 2 } \\
(\mathbf{S C})\end{array}$ & $\begin{array}{c}\text { Subscale 3 } \\
\text { (KAD) }\end{array}$ & $\begin{array}{c}\text { Subscale 4 } \\
\text { (CS) }\end{array}$ & $\begin{array}{c}\text { Subscale 5 } \\
\text { (CSE) }\end{array}$ \\
\hline$N$ & 204 & 245 & 238 & 236 & 237 & 226 \\
\hline Items & 66 & 10 & 17 & 13 & 10 & 16 \\
\hline Alpha & 0.963 & 0.877 & 0.883 & 0.904 & 0.910 & 0.844 \\
\hline
\end{tabular}

Note. $\mathrm{YR}=$ youth resilience, $\mathrm{SC}=$ social connections, $\mathrm{KAD}=$ knowledge of adolescent development, $\mathrm{CS}=$ concrete support in times of need, and CSE = cognitive and social-emotional competence.

Discriminant validity shows that measures of constructs that are not supposed to be related are in fact, unrelated. A Confirmatory Factor Analysis (CFA) was conducted on the data gathered in the second round to test for discriminant validity. That is, CFA was done to determine whether the items within one subscale are measuring the underlying protective and promotive factor and not another factor (Kline, 2011); thus, they would be unrelated. The CFA yielded a measurement that indicated that the instrument achieved marginal discriminant validity $(0.088)$. This finding suggests that although the items in each subscale are measuring a separate protective and promotive factor, there is also considerable overlap among the items in the 
subscales. This result is not surprising because the YT protective and promotive factors are interrelated, as are the items that were selected to measure them.

\section{Discussion}

Results of a multistage initial validation process show that the Youth Thrive Survey has high levels of internal consistency and reliability, both overall and within each of its five protective and promotive factor subscales. Table 5 provides examples of items included in the Youth Thrive Survey.

Table 5. Examples of Youth Thrive Survey Items

\begin{tabular}{|c|c|c|c|c|c|}
\hline Youth resilience & $\begin{array}{l}\text { Not at all } \\
\text { like me }\end{array}$ & $\begin{array}{l}\text { A little } \\
\text { like me }\end{array}$ & $\begin{array}{l}\text { Sort of } \\
\text { like me }\end{array}$ & $\begin{array}{l}\text { A lot like } \\
\text { me }\end{array}$ & $\begin{array}{l}\text { Very much } \\
\text { like me }\end{array}$ \\
\hline \multicolumn{6}{|l|}{$\begin{array}{l}\text { I believe I will be okay even when bad things } \\
\text { happen. }\end{array}$} \\
\hline \multicolumn{6}{|l|}{ I do a good job of handling problems in my life. } \\
\hline \multicolumn{6}{|l|}{ I give up when things get hard. } \\
\hline \multicolumn{6}{|l|}{ Failure just makes me try harder. } \\
\hline \multicolumn{6}{|l|}{$\begin{array}{l}\text { No matter how bad things get, I know the future } \\
\text { will be better. }\end{array}$} \\
\hline Social connections & $\begin{array}{l}\text { Not at all } \\
\text { like me }\end{array}$ & $\begin{array}{l}\text { A little } \\
\text { like me }\end{array}$ & $\begin{array}{l}\text { Sort of } \\
\text { like me }\end{array}$ & $\begin{array}{l}\text { A lot like } \\
\text { me }\end{array}$ & $\begin{array}{l}\text { Very much } \\
\text { like me }\end{array}$ \\
\hline \multicolumn{6}{|l|}{$\begin{array}{l}\text { There are people in my life who encourage me to } \\
\text { do my best. }\end{array}$} \\
\hline \multicolumn{6}{|l|}{ I have someone in my life who doesn't judge me. } \\
\hline \multicolumn{6}{|l|}{ I give up when things get hard. } \\
\hline \multicolumn{6}{|l|}{ I feel lonely. } \\
\hline $\begin{array}{l}\text { I do things to make the world a better place like } \\
\text { volunteering, recycling, or community service. }\end{array}$ & & & & & \\
\hline
\end{tabular}


Table 5. (continued)

\begin{tabular}{|c|c|c|c|c|c|}
\hline Knowledge of adolescent development & $\begin{array}{l}\text { Not at all } \\
\text { like me }\end{array}$ & $\begin{array}{l}\text { A little } \\
\text { like me }\end{array}$ & $\begin{array}{l}\text { Sort of } \\
\text { like me }\end{array}$ & $\begin{array}{l}\text { A lot like } \\
\text { me }\end{array}$ & $\begin{array}{l}\text { Very much } \\
\text { like me }\end{array}$ \\
\hline \multicolumn{6}{|l|}{$\begin{array}{l}\text { It's important for me to speak up for equality and } \\
\text { justice. }\end{array}$} \\
\hline \multicolumn{6}{|l|}{ I am proud of my race or ethnicity. } \\
\hline \multicolumn{6}{|l|}{ It's important for me to do the right thing. } \\
\hline \multicolumn{6}{|l|}{$\begin{array}{l}\text { I know what to do in case of an emergency at } \\
\text { home. }\end{array}$} \\
\hline \multicolumn{6}{|l|}{ I know how to take care of my personal hygiene. } \\
\hline Concrete support in times of need & $\begin{array}{l}\text { Not at all } \\
\text { like me }\end{array}$ & $\begin{array}{l}\text { A little } \\
\text { like me }\end{array}$ & $\begin{array}{l}\text { Sort of } \\
\text { like me }\end{array}$ & $\begin{array}{l}\text { A lot like } \\
\text { me }\end{array}$ & $\begin{array}{l}\text { Very much } \\
\text { like me }\end{array}$ \\
\hline \multicolumn{6}{|l|}{ I am able to go to a doctor when I need to. } \\
\hline \multicolumn{6}{|l|}{$\begin{array}{l}\text { I know how to get help with my personal } \\
\text { problems. }\end{array}$} \\
\hline \multicolumn{6}{|l|}{$\begin{array}{l}\text { I can stand up for myself when I feel that I am } \\
\text { treated unfairly. }\end{array}$} \\
\hline \multicolumn{6}{|l|}{ I can let people know what I need. } \\
\hline \multicolumn{6}{|l|}{ I have learned how to make good decisions. } \\
\hline $\begin{array}{l}\text { Cognitive and social-emotional } \\
\text { competence }\end{array}$ & $\begin{array}{l}\text { Not at all } \\
\text { like me }\end{array}$ & $\begin{array}{l}\text { A little } \\
\text { like me }\end{array}$ & $\begin{array}{l}\text { Sort of } \\
\text { like me }\end{array}$ & $\begin{array}{l}\text { A lot like } \\
\text { me }\end{array}$ & $\begin{array}{l}\text { Very much } \\
\text { like me }\end{array}$ \\
\hline \multicolumn{6}{|l|}{ I make plans and work hard to reach my goals. } \\
\hline \multicolumn{6}{|l|}{ I get along well with different types of people. } \\
\hline \multicolumn{6}{|l|}{ I am easily distracted. } \\
\hline \multicolumn{6}{|l|}{ I have difficultly controlling my anger. } \\
\hline I am sad most of the time. & & & & & \\
\hline
\end{tabular}

The Youth Thrive Survey is appropriate for use by organizations serving young people ages 12 to 26 , both those who are involved with intervening public systems and those who have no history of involvement. The survey can be used for assessment and case planning, program evaluation, and continuous quality improvement. By assessing youth strengths, the survey can help the youth-serving field shift toward adopting more asset-based policy, practice, and programming. The survey offers a valuable addition to existing measures of Positive Youth Development, providing a set of positive and multidimensional constructs in a single instrument 
that can be completed in approximately 15 minutes. It is currently being used in schools, colleges, and community-based organizations in addition to child welfare, public health, juvenile justice, and homelessness systems. Providing young people with the opportunity to engage in self-assessment of their protective and promotive factors can help to create avenues for more meaningful engagement in directing their case plans and the programs that impact their lives.

More research is needed to understand the ways in which organizations are using the survey and its relationship to improving outcomes for youth. To increase confidence in the findings from this validation study, the steps used in the current analysis should be replicated, and young people with different demographic profiles and involved with different service settings should be included, in future studies of the Youth Thrive Survey.

\section{References}

American Psychological Association. (2019). The road to resilience.

\section{https://www.apa.org/helpcenter/road-resilience}

Arthur, M. W., Hawkins, J. D., Pollard, J. A., Catalano, R. F., \& Baglioni, A. J. (2002). Measuring risk and protective factors for substance use, delinquency and other adolescent problem behaviors: The communities that care youth survey. Evaluation Review, 26, 575-601.

https://www.researchgate.net/publication/11004980 Measuring Risk And Protective Factors Fo r Substance Use Delinquency And Other Adolescent Problem Behaviors The Communities T hat Care Youth Survey

Barker, G. (2007). Adolescents, social support and help-seeking behaviour : An international literature review and programme consultation with recommendations for action. World Health Organization. https://apps.who.int/iris/handle/10665/43778

Bronfenbrenner Center for Translational Research. (2013). Translational neuroscience: Life and the adolescent brain. Cornell University, College of Human Ecology. www.human.cornell.edu/hd/people/upload/Life-and-the-Adolescent-Brain- -BCTR.pdf

Casey, B. J., Jones, R. M., \& Hare, T. A. (2008, March). The adolescent brain. Annals of the New York Academy of Sciences, 1124, 111-126. https://doi.org/10.1196/annals.1440.010

Catalano, R. F., Berglund, M. L., Ryan, J. A. M., Lonczak, H. S., \& Hawkins, J. D. (2002, June). Positive youth development in the United States: Research findings on evaluations of positive youth development programs. Prevention \& Treatment, 5(1). Article ID 15. https://doi.org/10.1037//1522-3736.5.1.515a 
Journal of Youth Development | http://jyd.pitt.edu/ | Vol. 16 Issue 4 DOI 10.5195/jyd.2021.933

The Youth Thrive Survey

Catalano, R. F., Gavin, L. E., \& Markham, C. M. (2010, March). Future directions for positive youth development as a strategy to promote adolescent sexual and reproductive health. Journal of Adolescent Health, 46(3) Supplement, S92-S96. https://doi.org/10.1016/j.jadohealth.2009.12.026

Choudhury, S., Blakemore, S.-J., \& Charman, T. (2006). Social cognitive development during adolescence. Social Cognitive and Affective Neuroscience, 1(3), 163-164.

Ciocanel, O., Power, K., Eriksen, A., \& Gillings, K. (2017, March). Effectiveness of positive youth development interventions: A meta-analysis of randomized controlled trials. Journal of Youth and Adolescence, 46(3), 483-504. https://doi.org/10.1007/s10964-016-0555-6

Cox, K. F. (2006). Investigating the impact of strength-based assessment on youth with emotional or behavioral disorders. Journal of Child and Family Studies, 15(3), 278-292. https://www.researchgate.net/publication/225563473 Investigating the Impact of StrengthBased Assessment on Youth with Emotional or Behavioral Disorders

Crone, E. A. (2009). Executive functions in adolescence: Inferences from brain and behavior. Developmental Science, 1-6. https://doi.org/10.1111/j.1467-7687.2009.00918.x

Dahl, R. E. (2004). Adolescent brain development: A period of vulnerabilities and opportunities (keynote address). Annals of the New York Academy of Sciences, 1021, 1-22.

Dunteman, G. H. (1989). Principal components analysis. Sage Publications.

Durlak, J. A., Weissberg, R. P., Dymnicki, A., \& Schellinger, K. B. (2011). The impact of enhancing students' social and emotional learning: A meta-analysis of school-based universal interventions. Child Development, 82(1), 474-501. https://doi.org/10.1111/j.14678624.2010.01564.x

Dymnicki, A. B., Menestrel, S. L., Boyd, M. J., Lauxman, L., Oberlander, S. E., Osher, D. (2016, December). Developing a federal research agenda for positive youth development: Identifying gaps in the field and an effective consensus building approach. Journal of Youth Development, 11(1), 5-19. https://doi.org/10.5195/jyd.2016.430

Easterbrooks, M. A., Ginsberg, K., \& Lerner, R. M. (2013, Fall). Resilience among military youth. The Future of Children, 23(2), 99-120. https://doi.org/10.1353/foc.2013.0014

Epstein, M. H. (2004). Behavioral and Emotional Rating Scale: A strength-based approach to assessment, Examiner's Manual (2 ${ }^{\text {nd }}$ ed.). PRO-ED.

Etikan, I. (2016, January). Comparison of convenience sampling and purposive sampling. American Journal of Theoretical and Applied Statistics. 5(1), 1-4. https://www.researchgate.net/publication/304339244 Comparison of Convenience Sampling a nd Purposive Sampling

Fergus, S., \& Zimmerman, M. A. (2005). Adolescent resilience: A framework for understanding healthy development in the face of risk. Annual Review of Public Health, 26, 399-419. https://www.annualreviews.org/doi/pdf/10.1146/annurev.publhealth.26.021304.144357 
Journal of Youth Development | http://jyd.pitt.edu/ | Vol. 16 Issue 4 DOI 10.5195/jyd.2021.933

The Youth Thrive Survey

Gavin, L. E., Catalano, R. F., David-Ferdon, C., Gloppen, K. M., \& Markham, C. M. (2010). A review of positive youth development programs that promote adolescent sexual and reproductive health. Journal of Adolescent Health, 46(3), S75-S91.

https://doi.org/10.1016/j.jadohealth.2009.11.215

Guerra, N. G., \& Bradshaw, C. P. (Eds.) (2008, Winter). Linking the prevention of problem behaviors and positive youth development: Core competencies for positive youth development and risk prevention. New Directions for Child and Adolescent Development, 2008 Winter(122). https://doi.org/10.1002/cd.225

Jaworska, N., \& MacQueen, G. (2015). Adolescence as a unique developmental period. (editorial). Journal of Psychiatry and Neuroscience, 40(5), 291-293. https://www.ncbi.nlm.nih.gov/pmc/articles/PMC4543091/pdf/ipn-40-291.pdf

Keating, D. P. (2004). Cognitive and brain development. In R. M. Lerner \& L. Steinberg (Eds.), Handbook of adolescent psychology ( $2^{\text {nd }}$ ed.). (pp. 45-84). John Wiley \& Sons.

Kline, R. B. (2011). Principles and practice of structural equation modeling ( $3^{\text {rd }}$ ed). Guilford Press.

Lerner, R. M. (2009). The positive youth development perspective: Theoretical and empirical bases of a strengths-based approach to adolescent development. In S. J. Lopez \& C. R. Snyder (Eds.), Oxford library of psychology: Oxford handbook of positive psychology, (2nd ed., pp.149-163). Oxford University Press.

Lerner, R. M., \& Lerner, J. V. (2013). Fact sheet. The positive development of youth: Comprehensive findings from the 4-H study of positive youth development. Tufts University, Institute for Applied Research in Youth Development. https://4-h.org/wp-content/uploads/2016/02/4-H-Study-ofPositive-Youth-Development-Fact-Sheet.pdf

Luthar, S. S. (Ed.). (2003). Resilience and vulnerability: Adaptation in the context of childhood adversities. Cambridge University Press.

Luthar, S. S., \& Cicchetti, D. (2000). The construct of resilience: Implications for interventions and social policies. Developmental Psychopathology, 12(4), 857-885. https://doi.org/10.1111/1467$\underline{8624.00164}$

Masten, A. S. (2001, March). Ordinary magic: Resilience processes in development. American Psychologist, 56(3), 227-238. https://pdfs.semanticscholar.org/54fd/cd219dd064230cf9d6a551dda717ce87598c.pdf? ga=2.123 26644.1713126608.1614050516-1889518223.1611894270

Murphey, D., Barry, M., \& Vaughn, B. (2013, January). Positive mental health: Resilience. Child Trends. https://www.childtrends.org/wp-content/uploads/2013/03/Child Trends$20131101 \mathrm{AHH}$ Resilience.pdf

National Institute of Mental Health. (2011). The teen brain: Still under construction. www.nimh.nih.gov/health/publications/the-teen-brain-still-under-construction/index.shtml 
Journal of Youth Development | http://jyd.pitt.edu/ | Vol. 16 Issue 4 DOI 10.5195/jyd.2021.933

The Youth Thrive Survey

National Scientific Council on the Developing Child. (2015). Supportive relationships and active skillbuilding strengthen the foundations of resilience: Working Paper 13. https://46y5eh11fhgw3ve3ytpwxt9r-wpengine. netdna-ssl.com/wp-content/uploads/2015/05/TheScience-of-Resilience2.pdf

Novick, E. R., Kim, J. I., Mazloomdoost, Y., Barthle, C., \& Hays, L. (2018). Adolescent health: Think, Act, Grow (TAG)-A strengths-based approach to promoting health in youth. Journal of Youth Development, 13(3), 97-110. https://doi.org/10.5195/jyd.2018.598

Peterson, C., \& Seligman, M. E. P. (2004). Character strengths and virtues: $A$ handbook and classification. American Psychological Association; Oxford University Press.

Resnick, M. D. (2005). Healthy youth development: Getting our priorities right. Medical Journal of Australia, 183(8), 398-400. https://doi.org/10.5694/j.1326-5377.2005.tb07101.x

Richter, L. M. (2006). Studying adolescence. Science, 312(5782), 1902-1905. www.ncbi.nlm.nih.gov/pmc/articles/PMC1866186

Steinberg, L. (2005, February). Cognitive and affective development in adolescence. Trends in Cognitive Science, $9(2), 69-74$.

United Nations Children's Fund. (2011). The state of the world's children 2011: Adolescence, an age of opportunity. www.unicef.org/sowc2011/pdfs/SOWC-2011-Main-Report EN 02092011.pdf

U.S. Department of Health and Human Services, Office of Adolescent Health. (2018, November). Adolescent Development Explained. U.S. Government Printing Office. https://opa.hhs.gov/sites/default/files/2020-08/opa-adolescent-development-explaineddownload.pdf

Unrau, Y. A., Conrady-Brown, M., Zosky, D., \& Grinnell, R. M. (2006). Connecting youth in foster care with needed mental health services: Lessons from research on help-seeking. Journal of EvidenceBased Social Work, 3(2), 91-109. https://doi.org/10.1300/j394v03n02 05

Werner, E. E. (2000). Protective factors and individual resilience. In J. P. Shonkoff \& S. J. Meisels (Eds.), Handbook of early childhood intervention (p. 115-132). Cambridge University Press. 